\title{
Introduction and Distributional Expansion of Trechus obtusus (Coleoptera: Carabidae) in Maui, Hawai ${ }^{\prime}{ }^{1}$
}

\author{
Fames K. Liebberr ${ }^{2}$ and Raina Takumi ${ }^{3}$
}

\begin{abstract}
Trechus obtusus Erichson (tribe Trechini), native to Europe and North Africa and introduced to the Pacific coast of North America, is recorded for the first time from East Maui Island, Hawai' $i$, based on collections made at Haleakalā National Park in September 1998. The species subsequently expanded its distribution to include Polipoli Springs State Recreation Area, East Maui. Range expansion has averaged $3 \mathrm{~km}$ per year, based on documented absence of $T . o b$ tusus from the Polipoli Springs area in 1998. All Hawaiian individuals are macropterous, even though European and North American populations of T. obtusus are dimorphic for wing configuration, with the brachypterous form most common in long-established populations. The source area for the Hawaiian invasion is hypothesized to be Oregon or the San Francisco Bay area, based on the closest match in the frequency of macroptery between specimens from Hawai' $i$ and those from those mainland areas. Monomorphic macroptery of the Hawaiian populations suggests that the founder population was small, with estimates ranging from as few as 6 individuals to as many as 25, assuming the founding propagule was drawn at random from populations in the western United States. Baseline abundance data are presented for Polipoli Springs State Recreation Area, where T. obtusus co-occurs with seven native Mecyclothorax species (tribe Psydrini), establishing the opportunity for long-term assessment of the impact of the introduced species on the sympatric native fauna. Means to identify $T$. obtusus in the context of the Hawaiian carabid beetle fauna are presented.
\end{abstract}

The Hawailan Islands are home to native carabid beetles representing three tribes: Mecyclothorax Sharp of the tribe Psydrini (Britton 1948a), several genera of the tribe Bembidiini (Britton 1948b), and Blackburnia Sharp of the tribe Platynini (Liebherr and Zimmerman 2000). The total described na-

${ }^{1}$ Partial support for fieldwork was provided by the National Geographic Society (grant no. 5929-97 to J.K.L.), and matching, collaborative support was provided by the Drake Memorial Fund of the National Museum of Natural History, Smithsonian Institution, administered by Dan A. Polhemus. Manuscript accepted 3 January 2002.

${ }^{2}$ Department of Entomology, Cornell University, Ithaca, New York 14853-0901.

${ }^{3}$ Haleakalā National Park, P.O. Box 369, Makawao, Maui, Hawai'i 96768.

Pacific Science (2002), vol. 56, no. 4:365-375

(C) 2002 by University of Hawai'i Press

All rights reserved tive fauna amounts to 241 species (Nishida 1997, Liebherr and Zimmerman 2000, Liebherr 2001), though a working estimate of 325 species is more likely, based on current revisionary taxonomic studies of Mecyclotborax (J.K.L., unpubl. data). An additional 25 exotic carabid beetle species have been adventively or purposefully introduced to Hawai'i (Davis and Krauss 1963, Davis and Butler 1964, Zimmerman 1972, Beardsley 1979, Nishida 1997). Most often these species were released or have been discovered in lowland situations such as agricultural fields, airports, or shipping ports, though a few have insinuated themselves into native ecosystems (Zimmerman 1972, Samuelson et al. 1997).

In this paper we report the introduction to Hawai' $i$ of Trecbus obtusus Erichson, the first representative of the carabid tribe Trechini to reach the Islands. This species currently occurs at $2000 \mathrm{~m}$ elevation on Haleakalā Volcano, in habitats also occupied by native Mecyclothorax carabid species. Continuing 
surveys of the insect fauna of Haleakalā permit us to unambiguously bracket the timing of distributional spread of T. obtusus over part of its known range on the Kula face of $\mathrm{Ha}$ leakalā. Moreover, substantial accumulated knowledge concerning the biology and historical distribution of this species (Kavanaugh and Erwin 1985) permits us to hypothesize the source of the Hawaiian founding population, estimate the founding propagule size, and make educated speculation concerning its means of entry to Hawai'i. Perhaps most important, we report results of sampling of both this species and syntopic native Carabidae to establish baseline abundance data permitting assessment of the long-term impact of this species on the native carabid fauna. We also provide modifications to the key to tribes included in Liebherr and Zimmerman (2000), permitting identification of this invasive species.

\section{MATERIALS AND METHODS}

\section{Collecting and Sampling}

Specimens collected for this study were obtained via several means. Specimens were found residing inside black plastic diphacinone rodenticide-bait stations. The diphacinone bait serves as a substrate for fungi, as well as lepidopterous and dipterous larvae, snails, and other invertebrates. Predatory carabid beetles enter the bait stations for shelter and presumably to feed. Specimens were collected from the bait stations by emptying the bait block and other contents, and retrieving the insects with forceps.

Recent field surveys for native Carabidae have involved several techniques relevant to this study. Beetles were collected on the soil surface by clearing an area of leaf litter. Beetles become active on the soil surface as it dries, with individuals escaping from soil cracks and also from the accumulated litter surrounding the bare soil. These were collected with an aspirator. This technique was termed "grubbing" by Perkins (Manning 1986).

Standardized leaf litter sampling has also been developed for comparative surveys at different sites. At each site, litter is sifted in a Reitter sifter (mesh size either 1.0 or $0.5 \mathrm{~cm}$ ), with the siftate poured onto a beating sheet and examined. Depending on field conditions, the siftate can be dried in the sun or inundated by rain, with beetles collected as they exit the drying or floating litter mass. During this study, the litter atop $4 \mathrm{~m}^{2}$ of forest floor constituted one unit litter sample.

A third component of recent insect surveys involves the use of synthetic pyrethrin insecticide in a fogging formulation that is applied to moss-covered trunks and branches, the bare bark surfaces of larger tree trunks such as 'ōhi'a lehua (Metrosideros polymorpha) or koa (Acacia koa), or to mossy rock faces along gulch faces. Before spraying, areas beneath the plant- or moss-covered surfaces are covered with cotton or nylon sheeting, allowing the insects exiting the substrate to be collected directly from the sheet into a specimen vial. Sheeting is maintained in place for 1-2 hr or until no specimens fall onto the sheet over any 15 -min period.

\section{Identification and Deposition}

Specimens of Trechus obtusus were identified by consulting Jeannel (1941), Lindroth (1961, 1985), and Lompe (1999). Specimens of $T$. obtusus and native Mecyclothorax mentioned in this paper are deposited in the Cornell University Insect Collection (cuic), Haleakalā National Park Collection (HALE), and $\mathrm{Na}$ tional Museum of Natural History, Smithsonian Institution, Washington, D.C. (NMNH). Representative vouchers have also been deposited at the Bernice Pauahi Bishop Museum and Hawai'i Department of Agriculture, Honolulu.

\section{RESULTS}

\section{Taxonomic Characterization}

To identify specimens of Trechus obtusus found in Hawaici, the characters of this taxon must be placed in the context of the native and introduced Hawaiian carabid beetle fauna. The recent treatment of the Hawaiian Platynini (Liebherr and Zimmerman 2000) included an introductory section with a di- 
chotomous key for identification to tribal level of any carabid beetle found in Hawai' $i$ (pp. 8-12). This key must be modified to accommodate the newly reported introduction. Insertion of the following couplets will permit identification of Trechus obtusus among all Hawaiian Carabidae. Figures from Liebherr and Zimmerman (2000) are listed as "fig.," whereas figures in this paper are listed as "Figure." Trechus obtusus is currently the only species of Trechini residing in Hawai' $i$; however, the key characters presented here will serve to diagnosis any members of the Trechini from other carabid taxa currently known from the Islands. Following the modifications to the key, we present diagnostic combinations that serve to identify Trechus obtusus relative to all current members of the Hawaiian carabid fauna (Local diagnosis) and relative to any potential future taxa, including trechines, that could be introduced to the Hawaiian fauna (Global diagnosis).

6(5) Apical labial and maxillary palpomeres subulate (i.e., much more slender, styliform compared to breadth of penultimate palpomeres (fig. 2A).............. Bembidiini Apical labial and maxillary palpomeres fusiform, at their broadest point of greater diameter than penultimate palpomeres (fig. $2 \mathrm{~B}$ ) $\ldots \ldots \ldots \ldots \ldots \ldots \ldots \ldots \ldots \ldots \ldots \ldots \ldots$

6a(6) Vertex of head with deep frontal sulci, curved semicircularly inside margin of eyes (Figure 1); elytral sutural stria recurrent apically, prolonged forward at the level of the fifth elytral stria (Figure 3$) \ldots \ldots \ldots \ldots \ldots \ldots \ldots \ldots \ldots \ldots \ldots$ Trechini

- Vertex of head with linear frontal sulci, divergent posteriorly, but not curved inside margin of eyes; elytral sutural stria approaching second stria apically, not recurved

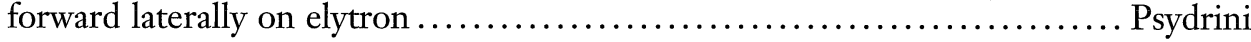

Trechus obtusus Erichson, 1837

Figures 1-4

LOCAL DiAgnosis. Distinguishable from all other currently known members of the Hawaiian carabid fauna by the deep semicircular frontal grooves (Figure 1), fusiform apical palpomeres nearly as broad as penultimate palpomeres, recurrent first elytral stria (Figure 3), and iridescent elytra. Standardized body length $3.2-4.3 \mathrm{~mm}$.

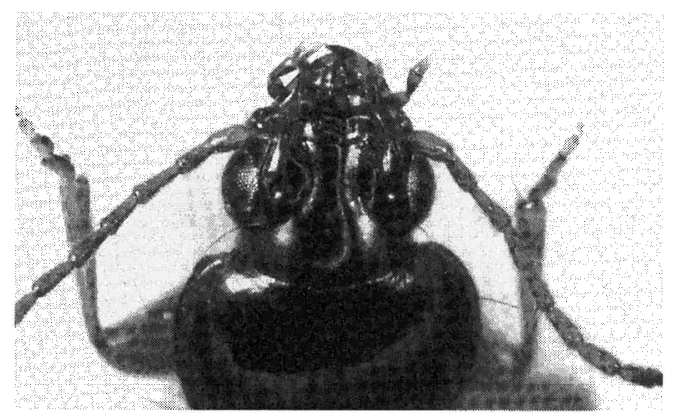

FIgURE 1. Trechus obtusus forebody, dorsal view, showing deep, semicircular frontal grooves diagnostic of tribe Trechini.
GLobal Diagnosis. Distinguishable from all other Trechus species by the broad pronotum, maximum width $1.5 \times$ median length, with obtuse hind angles (Figure 2); preapical seta situated closer to elytral stria 1 than recurrent stria, recurrent stria ending before connected with fifth elytral stria, the stria only faintly indicated near fourth stria (Figure 3); male aedeagus internal sac with two sclerotic plates (pl1 and pl2 [Lindroth 1961: 199, fig. $101 \mathrm{f}]$ ), each bearing short spikelike macrotrichia (Figure 4); apex of male median lobe slightly constricted on euventral side, curved slightly downward at tip.

Trechus obtusus is very similar externally to the sympatric Palearctic $T$. quadristriatus Schrank. The male aedeagus, however, includes reliable diagnostic characters for both species (see Jeannel 1941:328, fig. 128 for comparison).

COLlection Data. The initial discovery of Trechus obtusus in Hawai' $i$ was made during a survey of insects entering 10 diphacinone rodenticide-bait stations in the service area of Haleakalā National Park in 1998. Collecting data include the following: Hawai' $i$ : Maui, Haleakalā National Park, 20 46' 04" N, $156^{\circ}$ 


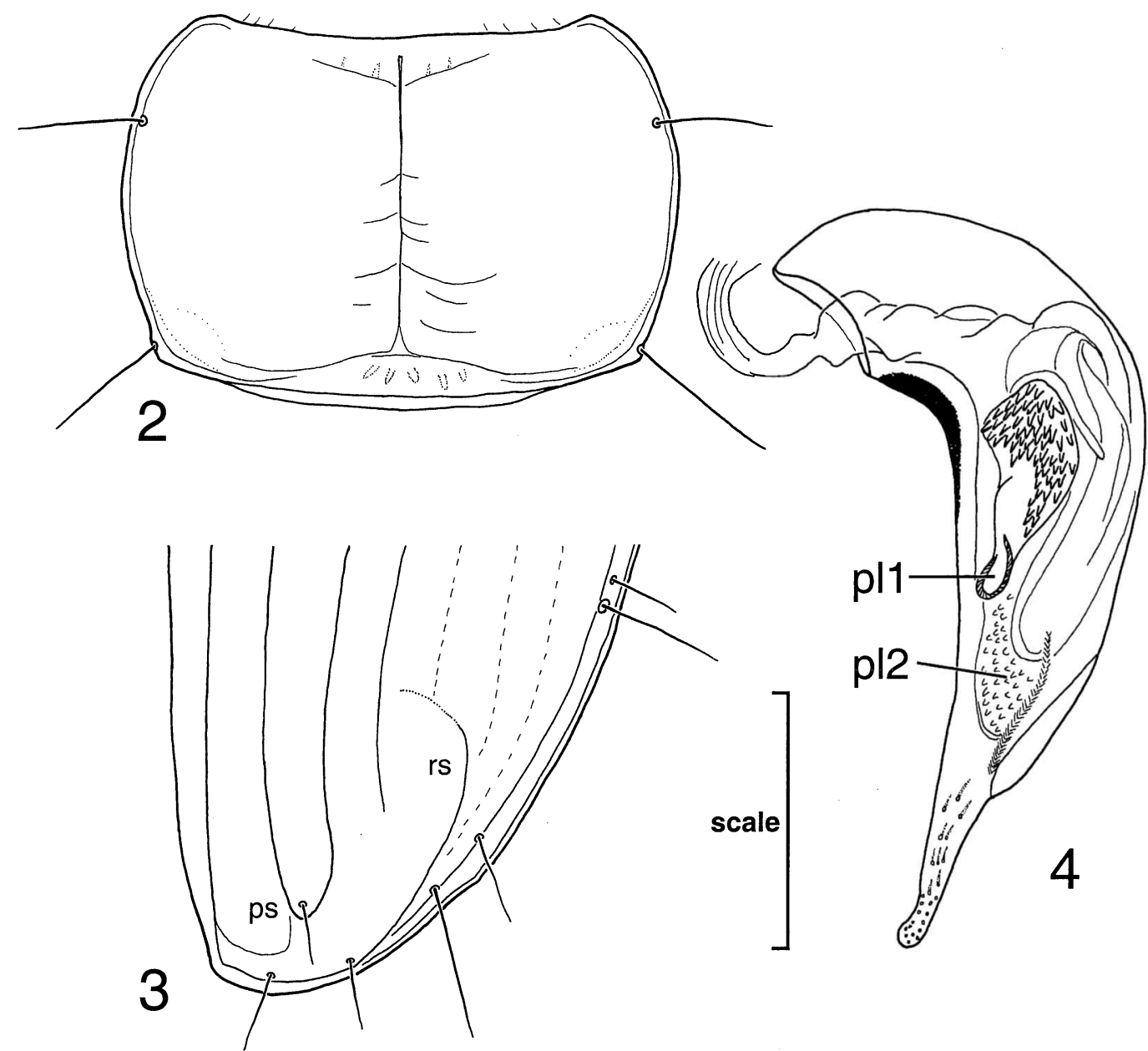

Figures 2-4. Trechus obtusus. 2, Pronotum, dorsal view. 3, Apex of right elytron; ps, preapical seta; rs, recurrent stria. 4, Median lobe of male aedeagus, left lateral view (ventral face in repose); $\mathrm{pl} 1$ and $\mathrm{pl} 2$ are sclerites of aedagal internal sac (Lindroth 1961). Scale bar $=0.50 \mathrm{~mm}$ (Figures 2, 3), $0.32 \mathrm{~mm}$ (Figure 4).

$14^{\prime} 45^{\prime \prime}$ W, 3 September 1998, el. $2073 \mathrm{~m}$, R. Takumi (1 male, 2 females; Hale, cuic). The beetles were found in the plastic rodenticidebait stations along with the undescribed native carabid Mecyclothorax sp. near "montivagus" (Table 1). Seven bait stations in place at the service area in 1997 were checked on 12 August. No Trechus beetles were found on that date.

Trechus obtusus was subsequently found at Polipoli Springs State Recreation Area, approximately $9.3 \mathrm{~km} \mathrm{SSW}$ of the Haleakalā National Park service area, in 2001. Adults of this species were collected at this site by various means (Table 1). Initial discovery on 19 May 2001 was made during nighttime grubbing in a small patch of mixed native and exotic vegetation. Approximately $8 \mathrm{~m}^{2}$ of forest floor was cleared of mixed gymnosperm needles (Sequoiadendron, Pinus) near a patch of native Pipturus and ferns, GPS coordinates $20^{\circ} 40^{\prime} 40^{\prime \prime} \mathrm{N}, 156^{\circ} 19^{\prime} 48^{\prime \prime} \mathrm{W}$. This resulted in collection of 18 Trechus beetles along with individuals of four species of native Mecyclothorax (Table 1). On 20 May 2001, T. obtusus was found via two other sampling methods in 
TABLE 1

Individual Collections of Trechus obtusus and Native Mecylothorax Carabid Beetles at Polipoli Springs State Recreation Area

\begin{tabular}{|c|c|c|c|c|c|c|c|c|c|c|c|c|}
\hline Date & Collector & Locality & Elev. (m) & Method & $\begin{array}{c}T . \\
\text { obtusus }\end{array}$ & $\begin{array}{c}M . \\
\text { irregularis }\end{array}$ & $\begin{array}{c}M . \\
\text { laetus }\end{array}$ & $\begin{array}{c}M . \\
\text { ovipennis }\end{array}$ & $\begin{array}{c}M . \\
\text { perstriatus }\end{array}$ & $\begin{array}{c}M . \\
\text { sobrinus }\end{array}$ & $\begin{array}{l}M . \text { sp. near } \\
\text { "aeneus" }\end{array}$ & $\begin{array}{l}M . \text { sp. near } \\
\text { "montivagus" }\end{array}$ \\
\hline 1 May 1998 & Liebherr & $\begin{array}{l}\text { Polipoli } \\
\text { Springs }\end{array}$ & 1,890 & $\begin{array}{c}\text { Grubbing, } \\
\text { day }\end{array}$ & & & 3 & & & 10 & & 35 \\
\hline 1 May 1998 & Ewing/Liebherr & $\begin{array}{l}\text { Polipoli } \\
\text { Springs }\end{array}$ & 1,890 & Under bark & & & 7 & & & & 1 & 19 \\
\hline 1 May 1998 & Liebherr & $\begin{array}{l}\text { S Polipoli } \\
\text { Springs }\end{array}$ & $1,950-2,000$ & Sifting litter & & & & & & & & 10 \\
\hline 19 May 2001 & Ewing/Liebherr & $\begin{array}{l}\text { Polipoli } \\
\text { Springs }\end{array}$ & 1,890 & $\begin{array}{c}\text { Grubbing, } \\
\text { night }\end{array}$ & 18 & & 6 & 1 & & & 2 & 33 \\
\hline 20 May 2001 & Liebherr & $\begin{array}{l}\text { NNW } \\
\text { Polipoli } \\
\text { Springs }\end{array}$ & 1,770 & Sifting litter & 78 & 2 & & & & 3 & & 15 \\
\hline 20 May 2001 & Polhemus & $\begin{array}{l}\text { NNW } \\
\text { Polipoli } \\
\text { Springs }\end{array}$ & 1,770 & $\begin{array}{l}\text { Pyrethrin } \\
\text { fog }\end{array}$ & 2 & & 1 & & 18 & 1 & 2 & 6 \\
\hline
\end{tabular}

Note: GPS coordinates for various lots listed in text. Specimens collected by Ewing and Liebherr deposited in cuic; specimens collected by Polhemus in NMNH. Species listed as near "aeneus" and "montivagus" are undescribed species most similar to described species with names in quotation marks; they are being described separately. 


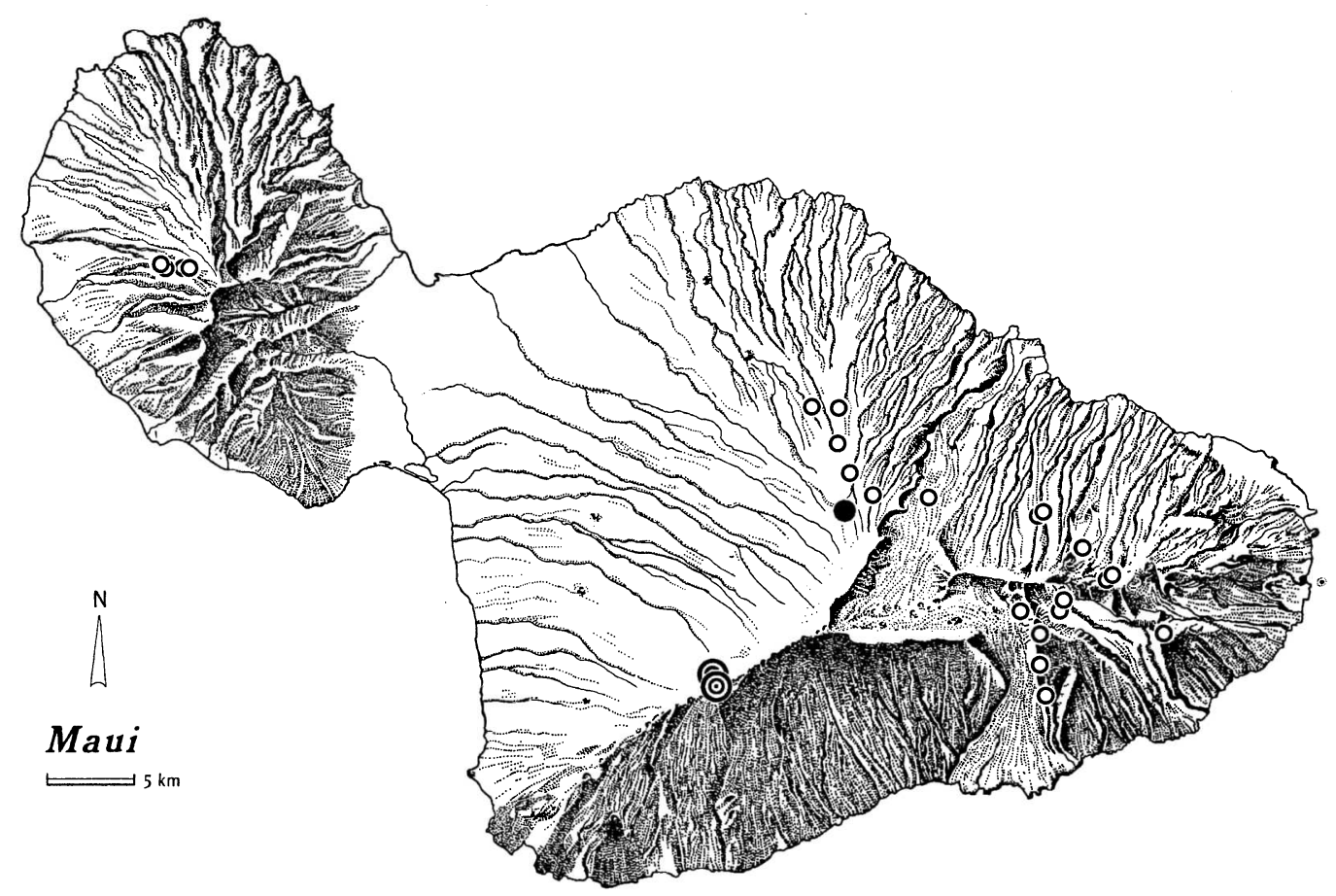

Figure 5. Distributional range of Trecbus obtusus: site of initial 1998 discovery (O); sites of collections during 2001 ()); sites where native Carabidae were sampled in 1998-2001 without discovery of T. obtusus (O).

a gulch bottom NNW of Polipoli Springs: (1) litter sifting under lower-stature native vegetation, and (2) pyrethrin fogging of a mossy rock face and contiguous mossy logs, GPS coordinates $20^{\circ} 41^{\prime} 17^{\prime \prime} \mathrm{N}, 156^{\circ} 19^{\prime} 57^{\prime \prime} \mathrm{W}$. At this site, $4 \mathrm{~m}^{2}$ of litter was sifted from among mossy rocks, low ferns, and understory vegetation. Trechus obtusus was the dominant species in the ground litter, accounting for nearly $80 \%$ of the observed carabid individuals. When mossy rock surfaces and adjacent aboveground moss-covered vegetation were fogged with pyrethrin insecticide, $T$. obtusus constituted a minor component of the sample, with the native Mecyclothorax perstriatus the most commonly observed carabid.

Polipoli Springs State Recreation Area was previously sampled for carabid beetles as part of a survey expedition to Maui undertaken in May 1998 (Table 1). During that visit, forest floor litter under Eucalyptus sp. and Monterey Cypress (Cupressus macrocarpa) was examined by grubbing during the daytime, 1 May 1998 . The site of this collection was within $100 \mathrm{~m}$ of the 19 May 2001 grubbing sample $\left(20^{\circ} 40^{\prime}\right.$ $\left.40^{\prime \prime} \mathrm{N}, 156^{\circ} 19^{\prime} 48^{\prime \prime} \mathrm{W}\right)$. Though nearly 50 native Mecyclothorax individuals representing three species were found in 1998, no T. obtusus individuals were observed. Individuals of three native Mecyclothorax species were also found under bark of exotic conifer logs (Picea, Pinus). A third 1998 sample constituted sifted forest floor litter from slightly higher elevation habitat $S$ of Polipoli Springs $\left(20^{\circ} 40^{\prime} 33^{\prime \prime}\right.$ $\left.\mathrm{N}, 156^{\circ} 19^{\prime} 10^{\prime \prime} \mathrm{W}\right)$; again, no T. obtusus individuals were observed.

Distribution. The currently known distribution of T. obtusus spans the Kula face of Haleakalā Volcano (Figure 5), with known inhabited sites ranging from approximately 1800 to $2000 \mathrm{~m}$ elevation. We have sampled numerous other sites on Maui for carabid beetles from 1998 to 2001 (Figure 5) and have found no other sites supporting T. obtusus. Though we cannot be certain of the ele- 
TABLE 2

Number of Brachypterous and Macropterous Specimens of Trecbus obtusus Reported by Kavanaugh and Erwin (1985) Subdivided by Geographic Region, and Gene Frequencies for Brachypterous and Macropterous Alleles Derived from Single-Gene Model of Wing Dimorphism Reported for Carabidae (See Text)

\begin{tabular}{lcccc}
\hline \hline Region & $\begin{array}{c}\text { No. } \\
\text { Brachypterous }\end{array}$ & $\begin{array}{c}\text { No. } \\
\text { Macropterous }\end{array}$ & $\begin{array}{c}\text { Gene Frequency } \\
\text { Brachyptery (p) }\end{array}$ & $\begin{array}{c}\text { Gene Frequency } \\
\text { Macroptery (q) }\end{array}$ \\
\hline British Columbia $^{\text {Washington }}{ }^{a}$ & 23 & 32 & 0.24 & 0.76 \\
Oregon $^{a}$ & 45 & 77 & 0.21 & 0.79 \\
San Francisco Bay area & 3 & 23 & 0.06 & 0.94 \\
\hline
\end{tabular}

${ }^{a}$ Washington and Oregon regions defined by geographic disjunctions in T. obtusus distribution (Kavanaugh and Erwin 1985, fig. 1) (i.e., Oregon region extends from Cowlitz County, Washington, on the north, to Del Norte County, California, on the south.

vational extent of its range, we conclude that the current range of T. obtusus is restricted to the Kula face of Haleakalā. The elevations of known invaded habitats lie near the timberline of native vegetation $(2000 \mathrm{~m})$ (i.e., sites where exotic conifers were planted during the twentieth century [Cuddihy and Stone 1990]).

FLight-WING CONFiguration. All 101 Hawaiian specimens of $T$. obtusus found through sampling activities to date were examined and found to possess fully developed (i.e., macropterous) metathoracic flight wings. Trechus obtusus populations in the western United States and Europe are composed of various proportions of macropterous and brachypterous individuals, the latter possessing only vestigial wing stubs without a reflexed wing apex. Flight-wing dimorphism in Carabidae of the genera Calathus Bonelli and Pterostichus Bonelli has been shown to be governed by a single pair of alleles, with the macropterous condition expressed only when the macropterous allele is homozygous (Lindroth 1946, Aukema 1986, 1990, Aukema et al. 1996). If it is assumed that this genetic mechanism governs wing dimorphism in $T$. obtusus-no other genetic mechanism has been demonstrated for wing dimorphism in Carabidae-then Hawaiian populations are fixed for the macropterous allele at the gene governing flight-wing development. Based on fixation at this locus, Hawaiian populations differ markedly from North American populations, in which the macropterous gene frequency ranges from 0.76 to 0.94 (Table 2).

\section{DISCUSSION}

\section{Source Population}

In North America, T. obtusus was first introduced to Seattle, Washington, in or before 1925 , most likely arriving via nursery stock originating in continental Europe ( $\mathrm{Ka}-$ vanaugh and Erwin 1985). It subsequently spread southward as far as Portland, Oregon, probably by natural means of dispersal. Currently disjunct populations in southern Oregon and the San Francisco Bay area were most likely established via subsequent human-assisted colonization on nursery stock originating in Portland. The species is currently distributed from the San Francisco Bay area north to Vancouver Island, British Columbia.

Based upon the discovery of T. obtusus on East Maui without any indication of its presence on any other island, the colonizing propagule most likely entered Maui directly from either a North American or a European population. Because shipping commerce directly to Maui originates predominantly on the American Pacific coast (Bess and Marcus 1998), it is reasonable to conclude based on commercial trade patterns alone that the Hawaiian propagules of T. obtusus originated via similar means: stowaways on commercial products originating on the Pacific coast of North America. Based on likely introductions to southern Oregon and California via nursery stock originating in Portland or farther north (Kavanaugh and Erwin 1985), a similar means of entry to Maui seems most probable. 
Fixation of the macropterous allele in Maui populations of T. obtusus is consistent with a western North American source for $T$. obtusus. Trechus obtusus populations in western North America are composed of a majority of macropterous individuals (Table 2), but populations in Europe are nearly completely brachypterous. For example, populations in Devon and Durham, England, are reported to be $100 \%$ brachypterous (Asteraki et al. 1995, Butterfield 1997, and pers. comm.), though Loxton (1982) reported a 4\% macroptery frequency for samples from Anglesey. Den Boer (1968) found that Dutch populations of T. obtusus varied greatly in macropter frequency: young colonizing populations in the reclaimed Flevoland polder comprised $95 \%$ winged individuals, but old, established populations in Drenthe comprised only 4\% macropters. Desender et al. (1980) reported evidence corroborating this pattern, with stable Belgian dune populations averaging 1\% macroptery; but higher percentages of macropters found at sites where the species was less abundant; presumably more recently colonized sites.

Therefore we conclude, based on comparing the fixed macropterous gene frequency for the Maui population with gene frequencies in all potential source regions of North America, that the sites most likely to have been the source for Maui T. obtusus include (1) the Oregon region, herein defined as extending from northern California to southern Washington State, including Portland; and (2) the San Francisco Bay area (Table 2).

\section{Founder Population Size}

Because the Hawaiian populations are monomorphically macropterous and the likely source propagules are composed of both macropterous and brachypterous individuals, the probabilities of randomly drawing genetically homozygous macropterous Hawaiian colonizing propagules of various sizes from the different North American regions (Kavanaugh and Erwin 1985) can be calculated. The assumption of a randomly drawn propagule is consistent with Kavanaugh and Erwin's conclusion that this species emigrated to North America and along the Pacific coast of North America in commercial shipments of nursery stock, without any requirement that winged individuals fly onto ships or cargo. Greater disparity in macropterous gene frequencies between source and colonist populations results in estimation of fewer colonizing individuals. Thus for the mainland populations characterized by lowest macropterous gene frequencies, probability of drawing a homozygous propagule from the mainland populations falls to $5 \%$ for sample sizes of only six or seven individuals (Figure 6). For the populations more closely matching macropterous gene frequency (San Francisco Bay area and Oregon [Table 2]), the probability of drawing a homozygous propagule falls to $5 \%$ at 15 and 25 individuals, respectively. Data from molecular markers such as mtDNA haplotypes, amplified fragment length polymorphisms (AFLPs), or microsatellite DNA (Stepien et al. 1998, Amsellem et al. 2000, Fonseca et al. 2000) could permit independent localization of the source population, permitting an assessment of the interaction between flight-wing gene frequency and colonizing propagule size. In any case, based on the data at hand a founder size of 25 or fewer individuals is proposed for any randomly determined colonizing propagule derived from the most likely source regions of the North American Pacific coast.

\section{Rate and Direction of Spread}

Based on arrival of $T$. obtusus at Polipoli Springs sometime between May 1998 and May 2001, this species has maximally expanded its range southwestward at a rate of 3 $\mathrm{km}$ per year. Of course, the rate of spread may be less if the range in 1998 was underestimated by our single sampled locality. Winged dispersal appears to be the means for range expansion over this period, because the prevailing winds along this face at midmountain elevations are toward the southwest (Giambelluca and Schroeder 1998). Conversely, other localities sampled in 1998 or later to the north and east of Haleakalā $\mathrm{Na}$ tional Park service area have not resulted in collection of T. obtusus (Figure 5). We are in 


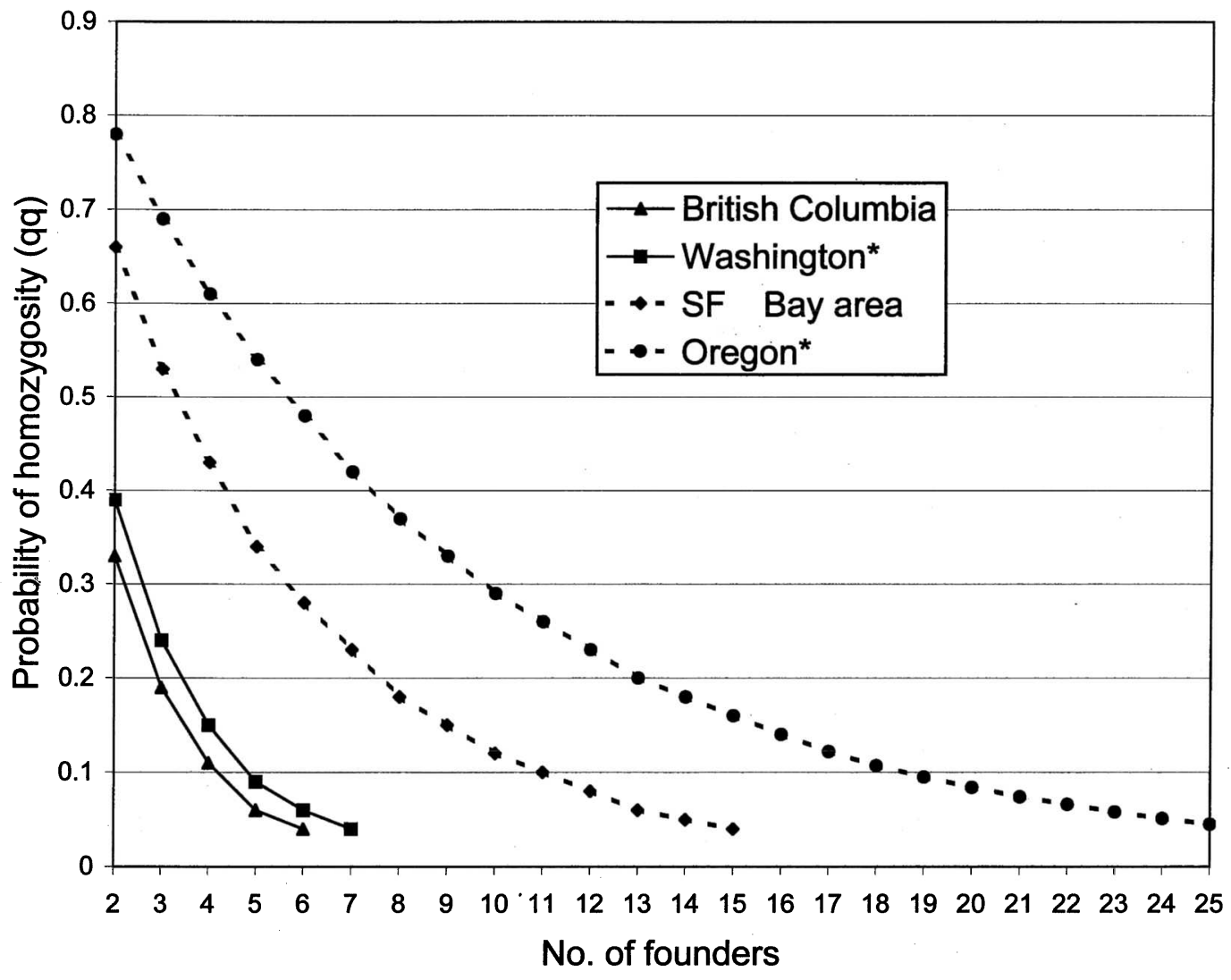

Figure 6. Probability of randomly drawing consistently homozygous, macropterous propagules of various sizes (individual genotypes qq, Table 2) from various regions composing the geographic distribution of Trecbus obtusus along the Pacific coast of North America.

the process of sampling the Waikamoi Gulch area (sites north and northeast of the Haleakalā National Park service area) to determine whether this species has invaded native forests along the leeward edge of the montane mesic and wet rain forest (as defined by Gagné and Cuddihy 1990).

\section{Impact on Native Biota}

Initial comparison of the Mecyclotborax fauna at Polipoli Springs before and after introduction of T. obtusus does not indicate any diminution of species richness at the site. To the contrary, sampling in 1998 resulted in discovery of four native species, whereas 2001 samples include seven native species (Table
1). Four Mecyclothorax species-the two undescribed species, $M$. laetus (Blackburn), and $M$. sobrinus Sharp-were found in both years. The three additional discovered species from 2001 can be explained by several means. First, the use of pyrethrin fog sampling permitted discovery of $M$. perstriatus (Sharp). This species is widespread across windward Haleakalā and is usually associated with moss mats on tree trunks and limbs above the ground. Thus its discovery at Polipoli is due to our sampling this microhabitat in 2001. Second, both $M$. perstriatus and $M$. irregularis Britton were found at sites near Polipoli Springs that had not been sampled previously, in this case a gulch bottom $120 \mathrm{~m}$ elevation below the initial sites. Finally, discovery of $M$. irregularis 
and $M$. ovipennis Sharp in very low numbers at Polipoli suggests that repeated sampling has permitted discovery of the relatively less abundant species in the area. Continued sampling may be predicted to uncover other numerically less dominant species in the resident Mecyclothorax species assemblage.

Though no impact on the native fauna is yet visible, the numerical abundance of $T$. obtusus at Polipoli is remarkable. In the San Francisco Bay and Oregon areas, T. obtusus is not particularly abundant when encountered; series of one to five are the norm (Kavanaugh and Erwin 1985). In contrast, sifting litter from $4 \mathrm{~m}^{2}$ of forest floor at Polipoli resulted in collection of 78 individuals, nearly twice as many as Kavanaugh and Erwin (1985) had available for study from the entire San Francisco Bay area.

We plan to continue sampling the Polipoli sites (Table 1) at timed intervals, using standardized $8 \mathrm{~m}^{2}$ grubbing samples, $4 \mathrm{~m}^{2}$ litter sifting samples, and pyrethrin fog samples. This effort will elucidate relative abundance of $T$. obtusus with species comprising the native Mecyclothorax fauna, as well as follow absolute abundance of this newly invading, tramp carabid species as it settles into its new home at Polipoli.

\section{ACKNOWLEDGMENTS}

We thank Ron Nagata of Haleakalā National Park, Betsy Harrison-Gagné, Bill Evanson, and Bob Hobdy of State of Hawai'i, Department of Land and Natural Resources, Division of Fish and Wildlife, for access to sites used in this study. We also thank the other members of the Bugstrafe 2001 Survey team (Curtis Ewing, Karl Magnacca, Hank Oppenheimer, and Dan Polhemus) for assistance in locating and sampling localities across Maui.

\section{Literature Cited}

Amsellem, L., J. L. Noyer, T. Le Bourgeois, and M. Hossaert-McKey. 2000. Comparison of genetic diversity of the invasive weed Rubus alceifolius Poir. (Rosaceae) in its native range and in areas of intro- duction, using amplified fragment length polymorphisms (AFLP) markers. Mol. Ecol. 9:443-455.

Asteraki, E. J., C. B. Hanks, and R. O. Clements. 1995. The influence of different types of grassland field margin on carabid beetle (Coleoptera, Carabidae) communities. Agric. Ecosyst. Environ. 54:195-202.

Aukema, B. 1986. Winglength determination in relation to dispersal by flight in two wing dimorphic species of Calathus Bonelli (Coleoptera, Carabidae). Pages 91-99 in P. J. den Boer, M. L. Luff, D. Mossakowski, and F. Weber, eds. Carabid beetles: Their adaptations, dynamics and evolution. Gustav Fischer, Stuttgart.

1990. Wing-length determination in two wing-dimorphic Calathus species (Coleoptera: Carabidae). Hereditas 113:189202.

Aukema, B., A. J. Spee, and T. S. Van Dijk. 1996. Wing dimorphism and development in Pterostichus melanarius (Coleoptera: Carabidae). Entomol. Ber. (Amst.) 56:93100.

Beardsley, J. W., Jr. 1979. New immigrant insects in Hawaii: 1962-1976. Proc. Hawaii. Entomol. Soc. 23:35-44.

Bess, D., and H. Marcus. 1998. Transportation. Pages 268-272 in S. P. Juvik and J. O. Juvik, eds. Atlas of Hawai'i. 3rd ed. University of Hawai'i Press, Honolulu.

Britton, E. B. 1948a. A revision of the Hawaiian species of Mecyclothorax (Coleoptera: Carabidae). Occas. Pap. Bernice Pauahi Bishop Mus. 19:107-166.

1948b. The carabid tribes Harpalini, Lebiini and Bembidiini in Hawaii (Coleoptera). Proc. Hawaii. Entomol. Soc. 13:235-254.

Butterfield, J. 1997. Carabid community succession during the forestry cycle in conifer plantations. Ecography 20:614-625.

Cuddihy, L. W., and C. P. Stone. 1990. Alteration of native Hawaiian vegetation. University of Hawai'i Press, Honolulu.

Davis, C. J., and G. D. Butler Jr. 1964. Introduced enemies of the giant African snail, Acbatina fulica Bowditch, in Hawaii (Pulmonata: Achatinidae). Proc. Hawaii. Entomol. Soc. 18:377-389. 
Davis, C. J., and N. L. H. Krauss. 1963. Recent introductions for biological control in Hawaii-VIII. Proc. Hawaii. Entomol. Soc. 18:245-249.

den Boer, P. J. 1968. Zoölogisch onderzoek op het Biologisch Station, Wijstger, 19591967. Misc. Pap. Landbouwhogesch. Wageningen 2:161-181.

Desender, K., J. P. Maelfait, and R. Deurinck. 1980. Ecological data on Trechus obtusus (Coleoptera, Carabidae) collected by pitfall trapping in coastal dunes (Belgium). Biol. Jaarb. Dodonaea 48:90-101.

Fonseca, D. M., D. A. LaPointe, and R. C. Fleischer. 2000. Bottlenecks and multiple introductions: Population genetics of the vector of avian malaria in Hawaii. Mol. Ecol. 9:1803-1814.

Gagné, W. C., and L. W. Cuddihy. 1990. Vegetation. Pages 45-114 in W. L. Wagner, D. R. Herbst, and S. H. Sohmer, eds. Manual of the flowering plants of Hawai'i. University of Hawai'i Press/Bishop Museum Press, Honolulu.

Giambelluca, T. W., and T. A. Schroeder. 1998. Climate. Pages 49-59 in S. P. Juvik and J. O. Juvik, eds. Atlas of Hawai'i. 3rd ed. University of Hawai'i Press, Honolulu.

Jeannel, R. 1941. Coléoptères Carabiques, première partie. Faune Fr. 39.

Kavanaugh, D. H., and T. L. Erwin. 1985. Trechus obtusus Erichson (Coleoptera: $\mathrm{Ca}-$ rabidae), a European ground beetle, on the Pacific coast of North America: Its distribution, introduction, and spread. Pan-Pac. Entomol. 61:170-179.

Liebherr, J. K. 2001. Blackburnia gastrellariformis sp. n. (Coleoptera: Carabidae), from Molokai: Successful prediction of a new taxon by reconciled tree analysis. Insect Syst. Evol. 32:133-141.

Liebherr, J. K., and E. C. Zimmerman. 2000. Hawaiian Carabidae (Coleoptera), Part 1:
Introduction and Tribe Platynini. Insects of Hawaii 16.

Lindroth, C. H. 1946. Inheritance of wing dimorphism in Pterostichus antbracinus Ill. Hereditas 32:37-40.

1961. The ground-beetles of Canada and Alaska. Opusc. Entomol. Suppl. 20:1200.

- 1985. The Carabidae (Coleoptera) of Fennoscandia and Denmark. E. J. Brill/ Scandinavian Science Press Ltd., Leiden/ Copenhagen.

Lompe, A. 1999. Revision der Trechus-Arten Madeiras und Porto Santos (Coleoptera, Carabidae). Entomol. Bl. Biol. Syst. Kaefer 95:93-143.

Loxton, R. G. 1982. Macropterous individuals of Trechus obtusus Erichson (Col., Carabidae). Entomol. Mon. Mag. 118:132.

Manning, A. 1986. The Sandwich Islands Committee, Bishop Museum, and R. C. L. Perkins: Cooperative zoological exploration and publication. Bishop Mus. Occas. Pap. 26:1-46.

Nishida, G. M. 1997. Hawaiian Terrestrial Arthropod Checklist. In Bishop Museum Technical Report No. 12. Hawai'i Biological Survey, Bishop Museum.

Samuelson, G. A., J. K. Liebherr, and K. W. Will. 1997. Gnathaphanus picipes, an established adventive in Hawaii (Coleoptera: Carabidae). Bishop Mus. Occas. Pap. 49: 22-23.

Stepien, C. A., A. K. Dillon, and M. D. Chandler. 1998. Genetic identity, phylogeography, and systematics of ruffe (Gymnocephalus) in the North American Great Lakes and Eurasia. J. Great Lakes Res. 24:361-378.

Zimmerman, E. C. 1972. On some foreign Carabidae established in Hawaii (Coleoptera). Proc. Hawaii. Entomol. Soc. 21:291-294. 